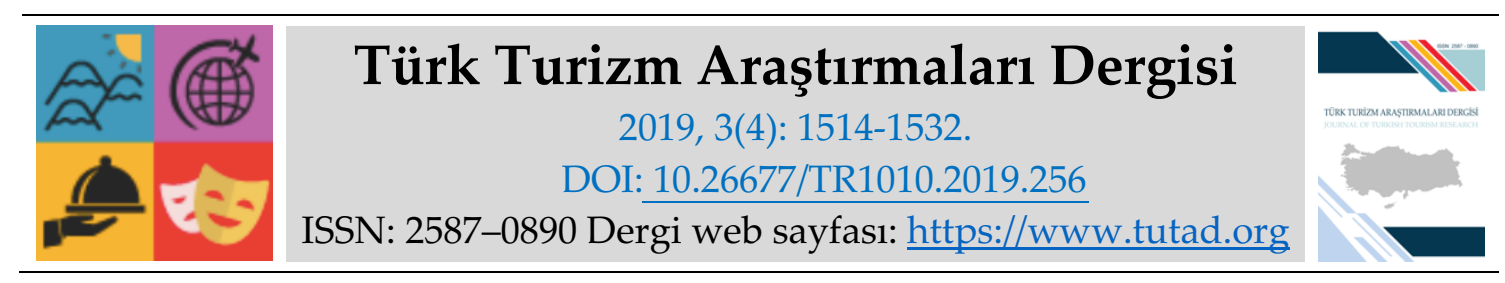

ARASTTIRMA MAKALESI

\title{
Destinasyon Kişiliği ile Memnuniyet ve Davranışsal Niyetler Arasındaki İlişkilerin İncelenmesi: Gaziantep Örneği
}

Doç. Dr. Nalan IŞIK, Gaziantep Üniversitesi, Turizm ve Otelcilik Meslek Yüksek Okulu, Gaziantep, e-posta: isiknalan@hotmail.com

ORCID: https://orcid.org/0000-0002-3072-649X

Burçin ÖZKAN, Yüksek Lisans Öğrencisi, Gaziantep Üniversitesi, Sosyal Bilimler Enstitüsü, Gaziantep, e-posta: burcinozkan92@gmail.com

ORCID: https://orcid.org/0000-0002-1371-2512

Öz

Bu çalışma, Gaziantep'in destinasyon kişiliğinin belirlenmesini ve destinasyon kişiliğine bağlı olarak yerli turistlerin memnuniyet ve davranışsal niyetleri arasındaki ilişkinin incelenmesini amaçlamıştır. Bunun için 2018 yılının Kasım ve Aralık aylarında Zeugma Mozaik Müzesi, Antep Kalesi ve Bakırcılar Çarşısını ziyaret eden yerli turistlere anket uygulanmıştır. Anket formlarının değerlendirilmesi için veriler faktör analizi, frekans analizi ve korelasyon analizi testlerine tabi tutulmuştur. Araştırma bulgularına göre, Gaziantep'in destinasyon kişiliği "modernlik" "samimiyet" "yetkinlik-seçkinlik" ve "huzur" şeklinde adlandırılan dört boyuttan oluşmuştur. Korelasyon analizi sonucunda destinasyon kişiliği boyutları ile turistlerin memnuniyet ve davranışsal niyetleri arasında pozitif yönlü bir ilişki olduğu tespit edilmiştir.

Anahtar Kelimeler: Marka Kişiliği, Destinasyon Kişiliği, Gaziantep.

Makale Gönderme Tarihi: 29.07.2019

Makale Kabul Tarihi: 03.10.2019

\section{Önerilen Atıf:}

Işık, N. ve Özkan, B. (2019). Destinasyon Kişiliği ile Memnuniyet ve Davranışsal Niyetler Arasındaki İlişkilerin İncelenmesi: Gaziantep Örneği, Türk Turizm Araştırmaları Dergisi, 3(4): 1514-1532.

(c) 2019 Türk Turizm Araştırmaları Dergisi. 


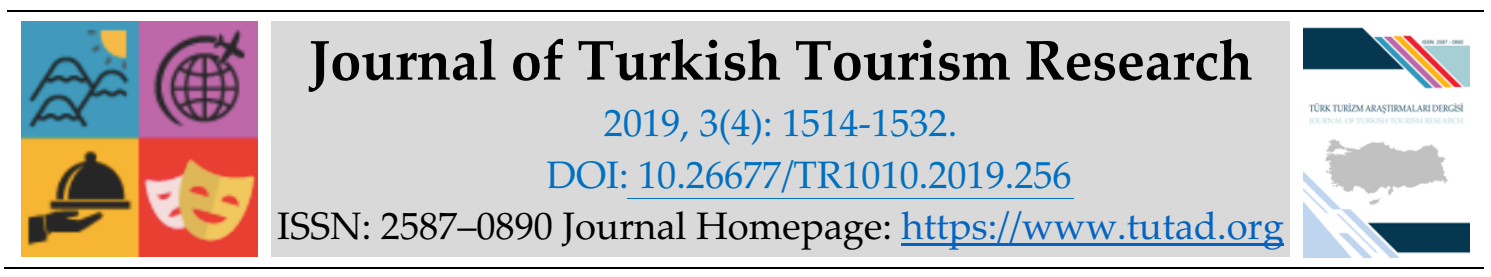

\title{
$\underline{\text { RESEARCH PAPER }}$
}

\section{The Examination of Relationships Between Destination Personality with Satisfaction and Behavioral Intentions: Case of Gaziantep}

Associate Prof. Dr. Nalan IŞIK, Gaziantep University, Vocational School of Tourism and Hotel Management, Gaziantep, e-mail: isiknalan@hotmail.com

ORCID: https://orcid.org/0000-0002-3072-649X

Burçin ÖZKAN, MSc, Gaziantep University, Social Sciences Institute, Gaziantep, e-mail: burcinozkan92@gmail.com

ORCID: https://orcid.org/0000-0002-1371-2512

\begin{abstract}
This study aimed to determine the locality of the destination of Gaziantep and to examine the relationship between the satisfaction and behavioral intentions of local tourists depending on the personality of the destination. For this purpose, in November and December of 2018, a survey was conducted to the local tourists visiting the Zeugma Mosaic Museum, Antep Castle and the Coppersmiths Bazaar. The questionnaire was prepared by adapting from the Brand Personality Scale of Aaker (1997). Data were analyzed by factor analysis, frequency analysis and correlation analysis to evaluate the questionnaire forms. According to the findings of the study, the destination of Gaziantep is composed of four dimensions called "modernity" "sincerity" "competence-exclusivity" and "serenity". As a result of the correlation analysis, it has been determined that there is a positive relationship between the dimensions of the destination personality and the satisfaction and behavioral intentions of the tourists.
\end{abstract}

Keywords: Brand Personality, Destination Personality, Gaziantep.

Received: 29.07.2019

Accepted: 03.10.2019

\section{Suggested Citation:}

Işık, N. and Özkan, B. (2019). The Examination of Relationships Between Destination Personality with Satisfaction and Behavioral Intentions: Case of Gaziantep, Journal of Turkish Tourism Research, 3(4): 1514-1532.

(C) 2019 Türk Turizm Araştırmaları Dergisi. 


\section{GİRIŞ}

Dünya genelinde hızla büyüyen turizm sektöründe rekabet oldukça yüksektir. Rekabet koşullarının zorlaşması, geleneksel pazarlama araçları turistleri destinasyona çekmede yetersiz kalmaktadır. Bu nedenle varlı̆̆ını sürdürmek isteyen veya rekabet gücünü yükseltmek isteyen destinasyonların diğer destinasyonlardan farklılaştırılması ve kendilerine has özelliklerinin markalaştırılması, etkili pazarlama araçlarından biri haline gelmiştir (Pereira vd., 2014:389). İnsanın sahip olduğu kişisel özelliklerinin marka ile ilişkilendirilmesi marka kişiliği olarak tanımlanmaktadır (Türkmen ve Köroğlu, 2017:399). 21. yüzyılda ürünlerin fiziksel özellikleri ve işlevsel faydalarının yanında ürünün markasının sembolik anlamı, tüketicilerin satın alma tercihlerini etkilemektedir (Artuğer ve Ercan, 2015:788). Marka kişiliği, Aaker (1997:347) tarafından "insana ait karakteristik özelliklerin bir marka ile bağdaştırılması" şeklinde tanımlanmaktadır. Markaların tüketicilerin zihninde insana özgü birtakım karakteristik özellikler taşıdığına ilişkin algı oluşturduğu belirtilmektedir (Aaker, 1997:347-348). "Coca Cola" markasının "havalı", "Pepsi" markasının "genç", "Malboro" markasının "erkeksi" kişilik özellikleri ile bağdaştırılması konuya ilişkin sıklıkla kullanılan örnekler arasında gösterilmektedir.

Marka kişiliği, müşteri ile marka arasında güçlü bir iletişim kurulmasına olanak sağlayarak markanın başarısında ve ürünün pazarlanmasında rol oynamaktadır. Tüketici, seçtiği markanın kendi kişiliğine uyumlu olmasını istemektedir. Bu şekilde, tüketici, markanın kendisini ifade ettiği hissine sahip olur. Tüketicinin zihnine yerleştirilen marka kişiliği, satın alma davranışlarını ve markaya yönelik tutumu ve gelecekte satın alma eğilimini etkilemektedir (Valette Florence vd., 2011:25).

Turizm sektöründe insanların ziyaret ettikleri ve belli bir süre konaklamayı tercih ettikleri yer olan destinasyonlar da marka kişiliğine sahiptir (Türkmen vd., 2018:22). Marka kişiliğinin destinasyonlara uyarlanmasıyla literatüre girmiş olan destinasyon kişiliği, "bir destinasyonla özdeşleştirilen insan özellikleri kümesi” olarak tanımlanmaktadır (Hosany vd., 2006:4). Hankinson (2004:155), destinasyon kişiliğini "bir yerin sahip olduğu fonksiyonel, sembolik ve deneyimsel özellikler" olarak tanımlamıştır. Destinasyon kişiliği “bir destinasyonla insan kişilik özelliklerinin ilişkilendirilmesini" ifade etmektedir (Ye, 2012:397). Bu bağlamda yapılan araştırmalarda turistler, İspanya'yı "arkadaş canlısı", Londra'yı "açık fikirli" ve Paris'i "romantik" kişilik özellikleri ile ilişkilendirmişlerdir (Xie ve Lee, 2013:539).

Turizm sektöründe artan rekabetle birlikte destinasyonlar, kendilerini diğer destinasyonlardan farklılaştırmak için kişiliklerini ön plana çıkararak daha tanınır olmak istemektedirler (Ülkü vd., 2017: 986-987). Bunun yanında akademik çalışmaların sonucu, destinasyon kişiliğinin turistlerin memnuniyet düzeylerini arttıran bir unsur olduğuna ve turistlerin davranışsal niyetleri (olumlu izlenim edinme, tekrar ziyaret ve tavsiye etme niyeti) üzerinde etkisi bulunduğuna işaret etmektedir (Murphy vd., 2007; Usakli ve Baloglu, 2011; Kılıç ve Sop, 2012; Umur ve Eren, 2016; Ural vd., 2016; Ülkü vd., 2017; Türkmen vd., 2018).

Gaziantep, UNESCO tarafından da belgelendirildiği gibi gastronomi turizmiyle öne çıkmaktadır. Her yıl yerli veya yabancı birçok turist, Gaziantep'in yiyecek içecek kültürünü tanımak amacıyla günübirlik turlarla veya bir gecelik konaklama yapmaktadır (https://gaziantep.ktb.gov.tr). Oysa Gaziantep ayn zamanda kültür ve tarihi ile de önemli bir kenttir. Ancak diğer kültürel özellikleriyle turist çekmede görece gastronomi turizmi kadar etkili olamamaktadır. Gaziantep'i ziyaret eden turistlerin destinasyonda daha uzun süre konaklamalarını sağlayacak etkili pazarlama çalışmalarının geliştirilmesi, destinasyonun cazibesinin ve turizmden elde edilen gelirin artmasına katkıda bulunabilir. 
Bu çerçevede çalışma ile Gaziantep'in kendine özgü destinasyon kişiliğinin ortaya konması amaçlanmıştır. Bu amaca bağlı olarak Gaziantep'in destinasyon kişiliği ile yerli turistlerin memnuniyet ve davranışsal niyetleri arasındaki ilişkinin ampirik olarak analiz edilmesi hedeflenmiştir. Elde edilen sonuçlar doğrultusunda Gaziantep'in destinasyon kişiliğinin belirlenmesinin olumlu marka imajı geliştirilmesi ve etkili destinasyon pazarlama stratejilerinin oluşturulmasına fayda sağlayacağı düşünülmektedir.

\section{LITERATÜR TARAMASI}

Araştırmanın bu bölümünde destinasyon kişiliğine ilişkin literatürde yapılmış olan yerli ve yabancı araştırmalar ile bu araştırmalardan elde edilen sonuçlar sunulmaktadır. Ayrıca bu araştırma örneklerinin farklı yönlerine de değinilmeye çalışılmıştır.

Ekinci ve Hosany (2006), Aaker'ın (1997) geliştirdiği "marka kişiliği ölçeği"ni turizm destinasyonlarına uygulayan ve destinasyon kişiliğini ilk kez inceleyen araştırmacılardır. Kanonik korelasyon analizinden yararlanılan çalışmada, iki farklı örneklem grubu oluşturulmuştur. Grubun birinde uluslararası seyahat eden turistler, diğerinde İngiliz turistler yer almaktadır. Analiz sonucunda İngiltere'nin "samimi", "heyecanlı" ve "eğlenceli" olarak üç destinasyon kişilik ölçeği ile tanımlanabileceği belirtilmiştir.

Murphy vd. (2007), Avustralya'nın Cairns ve Whitsundays destinasyonlarının kişilik yapılarını incelemek amacıyla yaptıkları çalışmada Aaker'ın (1997) marka kişiliği ölçeğinden yararlanmışlardır. Açıklayıcı faktör analizi ve regresyon analizi sonucunda Whitsundays'in destinasyon kişiliği, "zengin sinıflı", "dürüst", "heyecan verici" ve "çetin" olarak tanımlanırken, Cairns'in destinasyon kişiliği "samimi", "seçkin" ve "dışadönük" olarak açılanmıştır.

Kanıbir vd. (2010), İstanbul ve Roma'nın marka kişiliğini ölçmüşlerdir. Ekinci ve Hosany 'nin (2006) geliştirdiği ölçek kullanılmış ve elde edilen veriler T-testi, faktör analizi ve yapısal eşitlik modeli (YEM) ile test edilmiştir. Araştırmanın sonucunda Roma'nın marka kişiliği "yetkin", "heyecan verici", "içten" ve "çekici" şeklinde belirlenmiştir. İstanbul'un marka kişiliği de "heyecan verici", "içten" ve "dışadönük" olarak ifade edilmiştir.

Sahin ve Baloglu (2011), İstanbul'un destinasyon kişiliğini İstanbul'u ziyaret eden yabancı turistlere anket uygulayarak incelemişlerdir. Aaker'ın (1997) "marka kişiliği ölçeği"nden yararlandıkları araştırmada faktör analizi, one way anova ve korelasyon analizleri yapmışlardır. Araştırmanın bulguları, "yetkinlik-modernlik", "özgünlük-canlllı", "samimiyet", "karizmatikmodaya uygun" ve "eğlence" boyutlarının İstanbul'un destinasyon kişiliğini oluşturduğunu göstermektedir.

Usakli ve Baloglu (2011), Las Vegas'ın destinasyon kişiliğini ortaya çıkarmayı amaçlamışlardır. Bunun için Aaker'ın (1997), ölçeğini kullanarak 368 ziyaretçiye anket uygulamışlardır. Faktör analizi ve regresyon analizleri sonucunda Las Vegas'ın "canlı", "yetkinlik", "seçkinlik", "samimiyet" ve "çağdaşlık" boyutlarından oluştuğunu ortaya çıkarmışlardır.

Kılıç ve Sop (2012), Bodrum'un destinasyon kişiliğinin belirlenmesi ve Bodrum'un kişilik boyutları ile turistlerin memnuniyetleri arasındaki ilişkinin ölçülmesi amacıyla Bodrum'u ziyaret eden 252 yerli turistlere anket uygulamışlardır. Çalışmada Aaker'ın (1997) "marka kişiliği ölçeği” kullanılmış ve açıklayıcı faktör analizi ve regresyon analizleri gerçekleştirilmiştir. Çalışma sonucunda Bodrum'un kişilik özelliklerinin "dinamizm", "samimiyet", "yetkinlik" ve "seçkinlik" boyutları altında toplandığını ifade etmişlerdir. Ayrıca elde edilen bulgular "samimiyet" boyutunun destinasyon sadakati üzerinde en etkili kişilik özelliği olduğunu göstermektedir. 
Sop vd. (2012), destinasyon kişiliğinin destinasyon memnuniyetine etkisini araştırdıkları çalışmayı ise Bodrum'da tatil yapan 196 yerli turist ile gerçekleştirmişledir. Kılıç ve Sop'un (2012) çalışmasına benzer şekilde bu çalışmada da Bodrum'un "dinamik", "samimi", "yetkin" ve "entelektüel" bir yapısının olduğunu ortaya çıkarmışlardır. Ayrıca, çalışmada "dinamik" ve "samimi" destinasyon kişilik özelliklerinin memnuniyet üzerinde etkili olduğunu bulmuşlardır.

Ye (2012), Avustralya'nın destinasyon kişiliğini 210 Çin'li turiste anket uygulayarak belirlemeye çalışmıştır. Hosany vd. (2006)'nin “destinasyon kişiliği ölçeği”' nden faydalanılmış ve verilere faktör analizi ile çoklu regresyon analizi uygulanmıştır. Araştırmanın bulguları, Avustralya'nın destinasyon kişiliğinin "samimiyet", "heyecan", "seçkinlik" ve "sertlik" boyutlarından oluştuğuna işaret etmiştir.

Chen ve Phou (2013), Aaker'ın (1997) “marka kişiliği ölçeği"'ni kullanarak Kamboçya'nın Angkor Tapınağı Bölgesi'nin destinasyon kişiliğini araştırmışlardır. Çalışmalarında verilerin analizinde faktör analizi ve yapısal eşitlik modelinden yararlanılmıştır. 428 yabancı turiste uyguladıkları anket sonucunda Angkor Tapınağı Bölgesi'nin destinasyon kişiliğinin "heyecanlı", "samimiyet", "seçkinlik", "sertlik" ve "çağdaşlık" boyutlarından oluştuğu belirtilmiştir.

Kim ve Lehto (2013), Güney Kore'nin destinasyon kişiliğini ortaya çıarmak amacıyla Amerikalı turistler üzerinde bir araştırma gerçekleştirmişlerdir. Aaker'ın (1997) "marka kişiliği ölçeği" kullanılmış ve verilere içerik analizi ile faktör analizi uygulanmıştır. Araştırmanın sonucunda Güney Kore'nin destinasyon kişilik özelliklerinin "samimiyet", "heyecan", "yetkinlik", "seçkinlik" ve "sertlik" olarak beş boyutu olduğu tespit edilmiştir.

Xie ve Lee (2013), Çin'in başkenti olan Pekin'in destinasyon kişiliğini, Aaker'ın (1997) ölçeğini temel alarak 497 yabancı turiste anket uygulamışlardır. Faktör analizi sonucunda Pekin'in destinasyon kişiliğinin "heyecan", "yetkinlik", "seçkinlik" ve "sertlik" boyutlarında toplandığını belirtmişlerdir.

Artuğer ve Ercan (2015), birçok araştırmacı gibi Aaker'ın (1997 ölçeğini kullanarak Marmaris'in destinasyon kişiliğini araştırmışlardır. Veri setine açıklayıcı faktör analizi uygulayarak Marmaris'in destinasyon kişiliğinin "yeterlilik", "samimiyet", "heyecan verici" ve "sert" destinasyon kişilik özelliklerinden oluştuğunu belirtmişlerdir.

Sağlık ve Türkeri (2015), Palandöken Kayak Merkezi'nin destinasyon kişiliğini araştırmışlardır. Uşakli ve Baloglu (2011) ile Chen ve Phou (2013)'nın kullandıkları ölçeklerden yararlanan araştırmacılar, verileri faktör analizi, korelasyon analizi ve çoklu regresyon analizlerine tabi tutmuşlardır. Araştırma sonucunda Palandöken Kayak Merkezi'nin destinasyon kişiliği özelliklerinin "canlılık", "yetkinlik ve modern", "samimiyet" ve "entelektüellik" boyutları altında sınıflandırmışlardır.

Umur ve Eren (2016), destinasyon imajı ve destinasyon kişiliğinin memnuniyet ile gelecekte tekrar ziyaret etme niyeti üzerindeki etkisini ölçmeyi amaçlamışlardır. Bunun için Kapadokya'yı ziyaret eden yabancı turistlerden anket ile veri toplamışlardır. Uşaklı'nın (2009) çalışmasındaki ölçek kullanılmıştır. Toplanan veriler, merkezi eğilim ölçüleri, faktör analizi, korelasyon analizi ve regresyon analizlerine tabi tutulmuştur. Analiz bulgularına göre "hareket", "samimiyet", "huzur", "benzersizlik" ve "güzellik" olmak üzere Kapadokya'nın destinasyon kişilik özelliklerinin beş boyuttan oluştuğu tespit edilmiştir. Ayrıca katılımcıların destinasyon imajı ve destinasyon kişiliği algıları ile memnuniyet düzeyleri ve gelecekte tekrar ziyaret etme niyeti arasında anlamlı ve pozitif yönlü bir ilişki olduğu sonucu elde edilmiştir.

Ural vd. (2016), Hatay destinasyonunun destinasyon kişiliği ile bilişsel ve duygusal imajını araştırmışlardır. Bununla birlikte destinasyon kişiliği ve imajının tavsiye etme niyeti üzerindeki etkisini de ölçmüşlerdir. Destinasyon kişiliğinin ölçülmesi için Aaker (1997) ve Hosany vd., 
(2006)'nin ölçeklerinden hazırlanan anket yerli ziyaretçilere uygulanmıştır. Regresyon analizi bulgularına göre duygusal marka imajı ve destinasyon kişiliğinin, tavsiye etme niyeti üzerinde pozitif etkisi olduğu sonucuna varılmıştır.

Atay ve Dülgaroğlu (2017), Balıkesir'in Ayvalık ilçesine bağlı Cunda Adası'nın destinasyon kişiliğini belirlemek amacıyla bir araştırma yapmışlardır. Bunun için Aaker'ın (1997) marka kişiliği ölçeği ile yerli ve yabancı 511 turistten veri toplamışlardır. Yapılan faktör analizine göre Cunda Adası, "yetkinlik", "samimiyet", "seçkinlik", "dinamizm" ve "modernlik" destinasyon kişilik ölçeklerinde sınıflandırılmıştır.

Türkmen ve Köroğlu (2017), Türkiye ve Yunanistan'ın destinasyon kişiliklerini karşılaştırmayı amaçlamışlardır. Araştırmacılar destinasyon kişiliğinin ölçümünde Aaker'ın (1997) ve Hosany vd. (2006)'nin ölçeklerinden yararlanmışlardır. Veri seti, açıklayıcı faktör analizi ve T-testi ile analiz edilmiştir. Analizler sonucunda Türkiye'nin destinasyon kişiliğinin "yetkinlik-seçkinlik", "samimiyet" ve "sertlik", Yunanistan'ın destinasyon kişiliğinin ise "seçkinlik-heyecan", "samimiyet" ve "sertlik" boyutlarında toplandığı sonucunu elde etmişlerdir.

Ülkü vd. (2017), çalışmalarında Şanlıurfa'nın destinasyon kişiliğini araştırmışlar ve destinasyon kişiliği ile yerli turistlerin davranışsal niyetleri üzerindeki etkisini açıklamaya çalışmışlardır. Aaker'ın (1997) ölçeğinden yararlandıkları anketi 208 yerli turiste uygulamışlardır. Açılayıcı faktör analizi ve regresyon analizleri sonucunda Şanlıurfa'nın destinasyon kişiliğinin "heyecan ve entelektüellik", "samimiyet" ve "sertlik" boyutlarından oluştuğuna işaret etmiş̧ir. Ayrıca "samimiyet" boyutunun bütün boyutlar arasında davranışsal niyetler üzerinde en etkili ve olumlu yönde etkiye sahip olduğu belirlenmiştir.

Çetinsöz ve Atsan (2018), Anamur ilçesinin marka kimliğini ve marka kişiliğini belirlemeyi hedeflemişlerdir. Bunun için Artuğer ve Çetinsöz (2014)'ün çalışmasında kullandıkları ölçek ile bir anket hazırlamışlardır. Elde edilen verilere içerik analizi yapılmış, aritmetik ortalama ve standart sapma değerlerine bakılmıştır. Analizler sonucunda Anamur'un marka kişiliğinin "heyecan verici", "yeterlilik" ve "samimiyet" özelliklerinden oluştuğu bulgusuna ulaşmışlardır.

Türkmen vd. (2018), Çanakkale'nin yerli turistlerin algıladığ1 destinasyon kişiliğini tespit etmek ve destinasyon kişiliğinin, ziyaret memnuniyeti ile davranışsal niyetler arasındaki ilişkileri incelemek amacıyla 429 kişiye anket uygulamışlardır. Destinasyon kişiliği, Hosany vd.,'nin (2006) geliştirdiği ölçek ile değerlendirilmiştir. Elde edilen veriler açıklayıcı ve doğrulayıcı faktör analizine tabi tutulmuş, yapısal eşitlik modeli ile test edilmiştir. Analizler sonucunda Çanakkale'nin destinasyon kişiliği "yetkinlik-seçkinlik", "samimiyet", "güven" ve "heyecan" boyutlarının altında toplandığı sonucuna ulaşılmıştır. Ayrıca destinasyon kişiliğinin ziyaret memnuniyeti ve davranışsal niyetler üzerinde olumlu bir etkisinin olduğu tespit edilmiştir.

Destinasyon kişiliği konulu araştırmalarda genellikle Aaker (1997) ve Hosany vd.,'nin (2006) geliştirdiği ölçekler kullanılmıştır. Hem yerli hem yabancı turistler üzerinde araştırmalar yapılmıştır. Destinasyon kişiliğinin memnuniyet düzeyi, davranışsal niyetler, imaj ve sadakat gibi faktörler üzerinde etkili olup olmadığı araştırılmaktadır. Bunlara ek olarak analiz sonuçlarında destinasyon kişiliği boyutlarının farklı şekillerde ortaya çıktığı görülmektedir. Bunun nedeni her destinasyonun, her bölgenin farklı karakteristik özelliklere sahip olduğu algısıdır (Türkmen vd., 2018:23).

\section{YÖNTEM}

Gaziantep'in destinasyon kişiliği ve destinasyon kişiliğinin memnuniyet ile davranışsal niyetler arasındaki ilişkinin incelendiği bu çalışmada birincil veri toplama tekniklerinden olan anket 
tekniğinden yararlanılmıştır. Özellikle sosyal bilimler alanında en çok tercih edilen anket tekniği, araştırma evrenini/örneklemini oluşturan kişi veya gruplardan elde edilebilecek verilere tek tipleştirilmiş ifadelerle ulaşabilme amacıyla oluşturulan veri toplama aracıdır (Ural ve Kılıç, 2013:53). Destinasyon kişiliğini ölçen ifadeler, Aaker'ın (1997) geliştirdiği beş temel boyut ve 42 kişilik özelliğini içeren "marka kişiliği ölçeği" inden uyarlanmıştır. Ankette kullanılan ve 3 ifadeden oluşan "Ziyaret Memnuniyeti Ölçeği" ile 5 ifadeden oluşan "Davranışsal Niyetler Ölçeğ $i$ " İlban vd.'nin (2016) çalışmasından uyarlanmıştır.

Anket formu, iki bölümden oluşmaktadır. Birinci bölümde katılımcıların demografik ve tanıtıcı özelliklerine (cinsiyet, yaş, eğitim düzeyi, gelir düzeyi vb.) ilişkin sorular yer almaktadır. Katılımcların demografik ve tanıtıcı özellikleri, frekans değerleri ve yüzde dağılımıyla analiz edilmiştir. İkinci bölümde ise katılımcıların destinasyon kişiliği algıları, memnuniyet düzeyleri ve davranısssal niyetlerine ilişkin ifadeler bulunmaktadır. İkinci bölümde yer alan ifadeler, "1=kesinlikle katılmıyorum", " $5=$ kesinlikle katıllyorum" şeklinde olmak üzere 5'li Likert tipi ölçekle derecelendirilmiştir.

Araştırmanın evrenini Gaziantep'e gelen yerli turistler oluşturmaktadır. Gaziantep İl Kültür ve Turizm Müdürlüğü web sitesinden elde edilen bilgiye göre Gaziantep'i 2018 yılında 113.740 yerli turist ziyaret etmiş̧ir (https://gaziantep.ktb.gov.tr). Ural ve Kılıç (2013), 100.000 ve üzeri büyüklügündeki evrenlerde 0,05 hata payı ile en az 384 örneklem olması gerektiğini belirtmişlerdir. Araştırmada örneklemin belirlenmesinde kolayda örnekleme yöntemi kullanılmıştır. Gaziantep'i Kasım-2018 ve Aralık-2018 ayları arasında ziyaret eden ve araştırmaya katılmayı kabul eden 433 yerli turiste yüz yüze anket uygulanmıştır. Araştırmaya dâhil olan katılımcılardan Gaziantep'i bir insanmış gibi hayal etmeleri ve bu yolla anket sorularına yanıt vermeleri istenmiştir. Anketlerin 22 tanesi eksik ve hatalı olduğundan değerlendirme dişı bırakılmış ve 411 anket analize tabi tutulmuştur. Dolayısıyla çalışmanın örneklem büyüklügünün araştırma evrenini temsil etme kapasitesine sahip olduğu düşünülmektedir.

Araştırma kapsamında toplanan veriler IBM SPSS 21.0 for Windows paket programı ile analiz edilmiştir. Bir ankette olabilecek hataların tespit edilebilmesi için söz konusu anketin uygulanmasından önce bir ön test (pilot test) uygulanması önerilmektedir (Altunışık, 2008:8). Pilot uygulama, asıl uygulama için planlanan benzer koşullardan örneklemi temsil edebilecek daha küçük birimler üzerinde uygulanmaktadır. Pilot uygulama sonucunda aksayan yönler bulunursa düzeltilmekte, aksaklık yok ise asıl uygulamaya geçilmektedir (Karasar, 2014:156). Bu bağlamda anket formu, örneklem ile benzer özelliklere sahip 50 kişilik grup üzerinden uygulamaya tabi tutulmuştur. Pilot uygulamanın güvenilirlik ölçümü yapılmış ve Cronbach's Alpha katsayısının 0,80 olduğu tespit edilmiştir. Ayrıca gerçekleştirilen pilot uygulamanın verileri, araştırmanın amacına uygun olduğundan ve yeni bir soru eklenip çıkartılmadığından esas veriye dâhil edilmiştir. Ardından araştırmanın tamamı için asıl güvenilirlik ölçümü yapılmış ve destinasyon kişiliği ölçeğinin Cronbach's Alpha katsayısı, 0,89 olarak hesaplanmıştır. Özdamar'a (1999a:522) göre 0,80'den yukarı Cronbach's Alpha katsayısına sahip olan ölçek değerleri, "yüksek derecede" güvenilir kabul edilmektedir. Bu değer, ölçeğin güvenilir olduğunun işaretidir.

Veri setinin normal dağılıma uyup uymadığını tespit edebilmek amacıyla Kolmogorov-Smirnov Testi (n>30) uygulanmıştır. Tablo 1'de verilerin normal dağılmadığı görülmektedir $(p<0,05)$.

Destinasyon kişiliği ölçeğinin boyutlarının ortaya konması için veri setine açıklayıcı faktör analizi uygulanmıştır. Faktör analizi, birbiriyle ilişkili çok sayıda değişkeni bir araya getirerek az sayıda kavramsal olarak anlamlı yeni değişkenler (faktörler, boyutlar) bulmayı, keşfetmeyi amaçlayan çok değişkenli bir istatistiktir (Büyüköztürk, 2005:123). Faktör analizi değişken sayısının azaltılmasını ve değişkenlerin birbirleriyle olan ilişkilerinden yeni yapılar bulmayı 
sağlamaktadır. Bu sayede değişkenler gruplandırılmakta ve açılayıcı faktör yapıları oluşturulmaktadır (Özdamar, 1999b:233). Örneklem yeterliliği ve faktör analizinin geçerliliği Kaiser-Meyer-Olkin ve Bartlett küresellik testleriyle değerlendirilmiştir. Ayrıca katılımcıların destinasyon kişiliği, ziyaret memnuniyeti ve davranışsal niyetlerinin tespit edilmesi için ölçeklerin aritmetik ortalama ve standart sapma değerleri incelenmiştir.

Tablo 1. Ölçeklere Uygulanan Kolmogorov-Smirnov Testi Sonuçları

\begin{tabular}{|l|c|c|}
\hline \multicolumn{3}{|c|}{ Kolmogorov-Smirnov Testi } \\
\hline & İstatistik & P \\
\hline Destinasyon Kişiliği &, 164 &, 000 \\
\hline Memnuniyet &, 367 &, 000 \\
\hline Davranışsal Niyetler &, 274 &, 000 \\
\hline
\end{tabular}

Destinasyon kişiliğinin, turistler üzerindeki ziyaret memnuniyeti ve davranışsal niyet algıları arasındaki ilişkinin belirlenmesi için korelasyon analizi uygulanmıştır. Korelasyon analizi, iki değişken arasında ilişki ve bağımlılık olup olmadığını, var ise yönünü ve gücünü göstermek amacıyla kullanılan bir analiz tekniğidir (Yazıcıŏ̆lu ve Erdoğan, 2004:224).

\section{BULGULAR}

Araştırma analizlerinin ve bulguların yer verildiği bu kısımda, öncelikle katılımcıların demografik ve tanıtıcı özellikleri incelenmiştir. Ardından Gaziantep'in kişilik özelliklerine dair algıyı oluşturan boyutların tespit edilmesine yönelik bulgular sunulmuştur.

Katılımclara ait demografik ve tanıtıcı özelliklerin sunulduğu Tablo 2 incelendiğinde kadın katılımcıların oranının $(\% 52,6)$ erkek katılımcıların oranına $(\% 47,4)$ göre daha yüksek olduğu görülmektedir. Medeni durumlarına bakıldığında katılımcıların büyük bir kısmı evlidir (\%55). Örneklem içinde katılımcıların yaş dağılımlarının 46 yaş ve üzeri $(\% 30,4)$ ile $25-31$ yaş $(\% 27,5)$ gruplarında yoğunlaştığı anlaşılmaktadır. Katılımcıların eğitim düzeyleri incelendiğinde lisans eğitimi alanların $(\% 56,7)$ en fazla ziyaretçi grubunu oluşturduğu görülmektedir. Katılımcıların aylık gelir dağılımına göre 5001 ve üzeri $(\% 26,5)$ ile 2000 TL ve altı $(\% 25,1)$ gelire sahip olanların en fazla ziyaretçi grubunu oluşturduğu tespit edilmiştir. Katılımcıların Gaziantep'i öncellikli ziyaret nedenleri incelenmiştir. Katılımcıların büyük bir çoğunluğu, Gaziantep'in yöresel tatları $(\% 33,1)$ ile kültür ve tarihi $(\% 27,3)$ nedeniyle ziyaret ettiklerini belirtmişlerdir. Bu durum, Gaziantep'in gastronomi kenti olmasının yanında kültürel ve tarihi değerleriyle de öne çıkmaya başladığını göstermektedir.

Veri setinin faktör analizine uygunluğunun belirlenmesinde Kaiser- Meyer- Olkin (KMO) örneklem yeterliliği ve Bartlett küresellik testi sonuçları incelenmiştir. Faktör analizinin yapılabilmesi kapsamında KMO alt değeri için 0,70 (Altunışık vd., 2007:226) ve Bartlett küresellik testi için $\leq 0,05$ değerleri temel alınmıştır (Sipahi vd., 2010:79). Veri setine ilişkin KMO değeri ,900 olduğu ve Bartlett testine göre yaklaşık ki kare $\left(x^{2}\right)$ değerinin 2663,879 ve anlamlılık düzeyinin $\mathrm{p}=0.00$ olduğu tespit edilmiştir. Bu değerler, veri setinin faktör analizi için uygun olduğunu göstermektedir. Faktörlerin oluşturulmasında temel bileşenler analizi ve Direct Oblimin döndürme yönteminden yararlanılmıştır. Çalışmanın faktör analizinde eğik eksen döndürme metodu tercih edilmiştir. Faktör döndürme yöntemi kullanılmasının amacı yorumlanabilir ve adlandırılabilir faktörler elde etmektir (Sipahi vd., 2010:76). 
Tablo 2. Katılımcıların Demografik ve Tanıtıcı Özellikleri

\begin{tabular}{|c|c|c|}
\hline Değişkenler & (N) & $(\%)$ \\
\hline \multicolumn{3}{|l|}{ Cinsiyet } \\
\hline Kadın & 216 & 52,6 \\
\hline Erkek & 195 & 47,4 \\
\hline Toplam & 411 & 100,0 \\
\hline \multicolumn{3}{|l|}{ Medeni Durum } \\
\hline Evli & 226 & 55,0 \\
\hline Bekâr & 185 & 45,0 \\
\hline Toplam & 411 & 100,0 \\
\hline \multicolumn{3}{|l|}{ Yaş } \\
\hline $18-24$ & 61 & 14,8 \\
\hline $25-31$ & 113 & 27,5 \\
\hline $32-38$ & 77 & 18,7 \\
\hline $39-45$ & 35 & 8,5 \\
\hline 46 ve üzeri & 125 & 30,4 \\
\hline Toplam & 411 & 100,0 \\
\hline \multicolumn{3}{|l|}{ Eğitim Durumu } \\
\hline İlköğretim & 26 & 6,3 \\
\hline Lise & 54 & 13,1 \\
\hline Önlisans & 28 & 6,8 \\
\hline Lisans & 233 & 56,7 \\
\hline Lisansüstü & 70 & 17,0 \\
\hline Toplam & 411 & 100,0 \\
\hline \multicolumn{3}{|l|}{ Gelir Durumu } \\
\hline 2000 TL ve alt1 & 103 & 25,1 \\
\hline $2001-3000 \mathrm{TL}$ & 66 & 16,1 \\
\hline 3001-4000 TL & 68 & 16,5 \\
\hline $4001-5000 \mathrm{TL}$ & 65 & 15,8 \\
\hline 5001 ve Üzeri & 109 & 26,5 \\
\hline Toplam & 411 & 100,0 \\
\hline \multicolumn{3}{|c|}{ Öncelikli Ziyaret Nedeni } \\
\hline Yöresel Tatlar & 136 & 33,1 \\
\hline Kültür ve Tarih & 112 & 27,3 \\
\hline Yeni Yerler Görmek & 67 & 16,3 \\
\hline Aile / Arkadaş Ziyareti & 29 & 7,1 \\
\hline İş Seyahati & 22 & 5,4 \\
\hline Eğitim/Seminer & 16 & 3,9 \\
\hline Eğlence & 11 & 2,7 \\
\hline Toplantı/Konferans & 10 & 2,4 \\
\hline Spor & 8 & 1,9 \\
\hline Toplam & 411 & 100,0 \\
\hline
\end{tabular}

Açıklayıcı Faktör Analizi'nde (AFA) bir ifadeye ait yüksek iki faktör yükü arasında en az 0,10 fark olması önerilmekte ve yükler arasında $0,10^{\prime}$ dan küçük bir değer olduğu takdirde bu ifadeler binişik madde olarak adlandırılmaktadır (Türkmen ve Köroğlu, 2017:414). Farklı faktör altında 
yakın değerler alan maddelerin (binişik maddelerin) analizden çıkartılması önerilmektedir (Sipahi vd., 2010:25). Faktör analizlerinde bir faktör iki sorudan az olmamalıdır. Eğer tek sorudan oluşan bir faktör varsa bu maddenin faktör analizinden çıkartılması gerekmektedir (Sipahi vd., 2010:84-85). Faktör analizi sonucunda destinasyon kişiliği ölçeğindeki 3 madde (heyecan verici, göz kamaştırıcı, samimi) binişik madde olması, 2 madde (erdemli, cesur) faktör yükü düşük olması ve 1 madde (hayalperest) tek faktör altında yer alması sebepleriyle analizden çıartılmıştır. Ayrıca 1 madde (kaba davranan) faktör yükü -497 (etkisi negatif yönlü) olması sebebiyle analizden çıkartılması uygun bulunmuştur. Yukarıda belirtilen maddeler çıkartıldıktan sonra analiz tekrarlanmış ve tüm veriler kriterlere uygun hale gelmiştir. Dolayısıyla bu çalışmada destinasyon kişiliği ölçeği 4 boyut ve 17 ifadeden oluşmaktadır.

Tablo 3. Gaziantep Destinasyon Kişiliğgine İlişkin AFA Sonuçları

\begin{tabular}{|c|c|c|c|c|c|}
\hline Faktör İsmi & Kişilik İfadeleri & Faktör 1 & Faktör 2 & Faktör 3 & Faktör 4 \\
\hline \multirow{4}{*}{ Modernlik } & Çağdaş & ,733 & & & \\
\hline & Güvenilir & 731 & & & \\
\hline & Bağımsız & ,725 & & & \\
\hline & Batılı & 679 & & & \\
\hline \multirow{4}{*}{ Samimiyet } & Neşeli & & ,918 & & \\
\hline & Cana Yakın & & 860 & & \\
\hline & Yaşam Dolu & & ,605 & & \\
\hline & Özgün & & 490 & & \\
\hline \multirow{7}{*}{$\begin{array}{l}\text { Yetkinlik- } \\
\text { Seçkinlik }\end{array}$} & Zengin Sınıflı & & & ,777 & \\
\hline & Özgüvenli & & & ,636 & \\
\hline & Zeki & & &, 524 & \\
\hline & Başarılı & & &, 507 & \\
\hline & Güçlü & & & 491 & \\
\hline & Cekici & & & 462 & \\
\hline & İyi Görünümlü & & & 459 & \\
\hline \multirow[b]{2}{*}{ Huzur } & Aile Odaklı & & & & ,804 \\
\hline & Aklı Başında & & & &, 727 \\
\hline \multicolumn{2}{|l|}{ Özdeğerler } & 6,512 & 1,264 & 1,219 & 1,024 \\
\hline \multicolumn{2}{|c|}{ Faktörlerin Varyansı Açıklama Oranı } & 38,307 & 7,433 & 7,173 & 6,026 \\
\hline \multicolumn{3}{|c|}{ Toplam Varyansın Açıklanma Oranı } & \multicolumn{3}{|c|}{$\% 58,939$} \\
\hline \multicolumn{3}{|c|}{ Tüm Ölçeğin Cronbach's Alpha Değeri } & \multicolumn{3}{|c|}{0,890} \\
\hline \multicolumn{2}{|c|}{ Faktörlerin Cronbach's Alpha Değerleri } & 0,767 & 0,766 & 0,824 & 0,572 \\
\hline & \multicolumn{3}{|c|}{, 900} \\
\hline \multirow{3}{*}{ Bartlett Küresellik Testi } & & Kaiser-Meyer-Olkin Orneklem Olçümü & i-kare $\left(x^{2}\right.$ & 663,879 & \\
\hline & Testi & & $\mathrm{df}=136$ & & \\
\hline & & Sig & nlamlılık) & & \\
\hline
\end{tabular}

Tablo 3'te faktör analizi sonuçları sunulmuştur. Buna göre ölçeğin özdeğerinin 1'den büyük ve toplam varyansının \% 58,939 olduğu ve dört faktörden oluştuğu tespit edilmiştir. İfadelere ilişkin faktör yüklerinin tamamı 0.40 değerinin üzerindedir.

Birinci faktöre ait özdeğer 6,512 ve faktörün ölçeği açıklama yeterliliği olarak görülen varyans oranı 38,307 dir. Birinci faktörde 4 ifade yer almıştır. Bu ifadeler, orijinal ölçekte heyecan, yetkinlik ve sertlik boyutlarında bulunmaktadır. Bu araştırmada ilgili ifadelerin toplandığ boyut, "modernlik" olarak adlandırılmıştır. İkinci faktöre ait özdeğer 1,264 ve faktörün ölçeği 
açılama yeterliliği olarak görülen varyans oranı 7,433'tür. İkinci faktörde 4 ifade yer almıştır. Bu ifadeler, orijinal ölçekte "samimiyet" boyutunda yer almıştır. Bu yüzden bu boyut, "samimiyet" olarak adlandırılmıştır. Üçüncü faktöre ait özdeğer 1,219 ve faktörün ölçeği açıklama yeterliliği olarak görülen varyans oranı 7,173’ tür. Üçüncü faktörde 7 ifade yer almıştır. Bu ifadeler orijinal ölçekte yetkinlik ve seçkinlik boyutlarında yer almıştır. Bu yüzden bu boyut "yetkinlik-seçkinlik" olarak tanımlanmıştır. Dördüncü faktöre ait özdeğer 1,024, faktörün ölçeği açılama yeterliliği olarak görülen varyans oranı 6,026' dır. Dördüncü faktörde 2 ifade yer almıştır. Bu ifadeler orijinal ölçekte samimiyet boyutunda yer almıştır. Bu çalışmada ise "huzur" boyutu olarak adlandırılmıştır.

Tablo 3'te faktörlere ait madde numaraları ve faktörlerin Cronbach's Alpha değerleri verilmiştir. Buna göre Cronbach's Alpha değerleri "modernlik" boyutu için 0,767; "samimiyet" boyutu için 0,766; "yetkinlik-seçkinlik" boyutu için 0,824; "huzur" boyutu için ise 0,572 olarak bulunmuştur. Tüm ölçeğin Cronbach's Alpha değeri, 0,890 olarak tespit edilmiştir. Güvenilirlik analizinin ilk olarak her faktör için ayrı ayrı uygulanması, daha sonra da bütüne bakılması önerilmektedir. Özellikle Cronbach's Alpha değeri örneklem ve ifade sayısıyla birlikte yükselme eğilimi gösterdiğinden bütünden çok faktör düzeyinde sonuçların daha hassas olduğu kabul edilmektedir (Yaşlığlu, 2017:78). Buna göre araştırmada huzur boyutuna ilişkin Cronbach's Alpha değeri, diğer boyutlardan daha düşük çıkmıştır. Kehoe (1995) az sayıda maddeden oluşan ölçeklerin güvenirliklerini değerlendirirken Cronbach's Alpha değerinin 0,50 olmasının yeterli olacağını, alt boyutlarda yer alan madde sayısının az olmasının güvenilirlik katsayılarının düşük çıkmasına neden olabileceğini ifade etmiştir (Çiğdem ve Kurt, 2012:489).

Tablo 4. Destinasyon Kişiliğine İlişkin İfadelerin Değerlendirilmesi

\begin{tabular}{|l|c|c|}
\hline Boyutlara Göre İfadeler & $\begin{array}{c}\text { Aritmetik Ortalama } \\
\text { Modernlik Boyutu }\end{array}$ & $\begin{array}{c}\text { Standart Sapma } \\
\text { s.s }\end{array}$ \\
\hline Çağdaş & $\mathbf{3} \mathbf{9 2}$ &, 858 \\
\hline Güvenilir & 4,09 &, 926 \\
\hline Bağımsız & 3,84 &, 784 \\
\hline Batılı & 4,05 &, 783 \\
\hline Samimiyet Boyutu & 3,69 &, 940 \\
\hline Neşeli & $\mathbf{4 . 2 9}$ &, $\mathbf{6 8 8}$ \\
\hline Cana Yakın & 4,18 &, 703 \\
\hline Yaşam Dolu & 4,34 &, 648 \\
\hline Özgün & 4,06 &, 783 \\
\hline Yetkinlik-Seçkinlik Boyutu & 4,58 &, 619 \\
\hline Zengin Sınıflı & 4.25 &, 701 \\
\hline Özgüvenli & 3,96 &, 892 \\
\hline Zeki & 4,35 &, 613 \\
\hline Başarılı & 4,18 &, 658 \\
\hline Güçlü & 4,47 &, 659 \\
\hline Çekici & 4,31 &, 662 \\
\hline İyi Görünümlü & 4,39 &, 702 \\
\hline Huzur Boyutu & 4,06 &, 721 \\
\hline Aile Odaklı & 4.18 &, 768 \\
\hline Aklı Başında & 4,42 &, 670 \\
\hline
\end{tabular}

* 1,00-1,79: Oldukça Düşük Düzey; 1,80-2,59: Düşük Düzey; 2,60-3,39: Orta Düzey; 3,404,19: Yüksek Düzey; 4,20-5,00: Çok Yüksek Düzey, N=411 
Faktör analizinin ardından Tablo 4'te Gaziantep'in destinasyon kişiliğinin ortaya konulmasına ilişkin bulgular sunulmaktadır. İlgili tabloya göre Gaziantep'in destinasyon kişiliğine ilişkin en

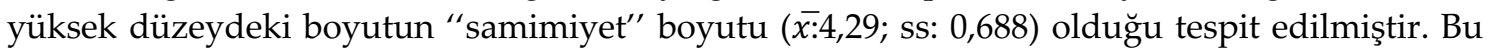
boyutu sırasiyla "yetkinlik-seçkinlik" boyutu $(\bar{x}: 4,25$; ss: 0,701$)$ ve huzur boyutu $(\bar{x}: 4,18$; s.s: 0,768 ) izlemektedir. Diğer bir ifade ile Gaziantep'i ziyaret eden yerli turistler değerlendirmesi, Gaziantep'in "neşeli, cana yakın, yaşam dolu, özgün, zengin sınıflı, özgüvenli, zeki, başarılı, güçlü, çekici, iyi görünümlü, aile odaklı ve aklı başında" kişilik özelliklerine sahip olduğu yönündedir. Gaziantep'in destinasyon kişiliğine ait en düşük boyut ise "modernlik" ( $\bar{x}$ : 3,92; s.s: 0,858) olarak belirlenmiştir. Bu değerler, Gaziantep'in destinasyon kişiliğinin oluşmasında samimiyet, yetkinlik-seçkinlik ve huzur boyutlarının daha belirleyici olduğunu; modernlik boyutunun ise biraz daha geride kaldığını göstermektedir. Katılımcılar, Gaziantep'i bir kişilik

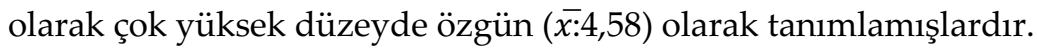

Tablo 5. Ziyaret Memnuniyeti ile Davranışsal Niyetleri Belirlemeye Yönelik Bulgular

\begin{tabular}{|l|c|c|}
\hline İfadeler & $\overline{\mathbf{x}}$ & S.S. \\
\hline Gaziantep'i ziyaret etmekle çok doğru bir karar verdim & 4,70 &, 536 \\
\hline Genel olarak Gaziantep ziyaretimden memnunum & 4,70 &, 541 \\
\hline Gaziantep ziyaret beklentilerimi karşıdladı & 4,60 &, 681 \\
\hline & 4.66 &, 586 \\
\hline Gaziantep'i gelecekte tekrar ziyaret etmek isterim & 4,65 &, 653 \\
\hline Gaziantep hakkında olumlu ifadeler kullanırım & 4,61 &, 607 \\
\hline Arkadaşlarıma/yakınlarıma Gaziantep'i ziyaret etmelerini tavsiye ederim & 4,72 &, 557 \\
\hline Gaziantep'i diğer insanlara anlatmaktan gurur duyarım & 4,50 &, 716 \\
\hline Gaziantep hakkında olumsuz bir düşüncem yok & 4,58 &, 690 \\
\hline & $\mathbf{4 . 6 1}$ &, $\mathbf{6 4 4}$ \\
\hline
\end{tabular}

*1,00-1,79: Oldukça Düşük Düzey; 1,80-2,59: Düşük Düzey; 2,60-3,39: Orta Düzey; 3,404,19: Yüksek Düzey; 4,20-5,00: Çok Yüksek Düzey, N=411

Gaziantep'in destinasyon kişiliğinin ortaya konulmasının devamında katılımcıların Gaziantep ziyaretlerinden memnuniyetleri ile davranışsal niyetlerinin belirlenmesi amaciyla 3 ifadeden oluşan "Ziyaret Memnuniyeti Ölçeği" ile 5 ifadeden oluşan "Davranışsal Niyetler Ölçeğì" analize tabi tutulmuştur. Elde edilen bulgular, 5 ve 6 numaralı tablolarda sunulmuştur. Buna göre araştırmaya katılan turistlerin memnuniyet düzeyleri $(\bar{x}$ : 4.66 ; s.s: 0,586$)$ ve davranışsal niyetleri $(\bar{x}: 4.61$; s.s: 0,644) çok yüksek düzeydedir. Bu veriler, Gaziantep'i ziyaret eden yerli turistlerin Gaziantep'ten genel olarak memnun kaldıklarını, gelecekte Gaziantep'i yeniden ziyaret etmek istediklerini veya yakınlarına Gaziantep'i tavsiye edebileceklerini göstermektedir.

Araştırmanın konusu olan destinasyon kişiliği boyutları ile memnuniyet ve davranışsal niyetler arasındaki ilişki korelasyon analizine tabi tutulmuştur. Değişkenlerin normal dağılım gösterdiği durumlarda Pearson korelasyon katsayısı hesaplanmakta, normal dağılım göstermediğinde ise Spearman Brown Korelasyon katsayısı hesaplanmaktadır (Olcay ve Düzgün, 2016:1139). Kolmogorov Smirnov testine tabi tutulan (Tablo 1) verilerin normal dağılım göstermediği anlaşılmıştır. Bu nedenle destinasyon kişiliği ile memnuniyet ve davranışsal niyetler arasındaki ilişki Spearman Brown Korelasyon katsayısı kullanılarak hesaplanmıştır.

Korelasyon katsayısı, iki değişken arasındaki ilişkinin miktarını bulup yorumlamak amacıyla kullanılır. İki değişken için hesaplanan korelasyon katsayısı (r), -1 ile +1 arasında değerler alabilmektedir $(-1 \leq r \leq+1)$. Korelasyon katsayısı 1.00 olduğunda mükemmel pozitif ilişki olduğu; -1.00 
olduğunda mükemmel negatif ilişki olduğu; 0.00 olduğunda ise ilişki olmadığı şeklinde yorumlanmaktadır. Korelasyon katsayısının, mutlak değer olarak 0.70-0.99 arasında olması güçlü, 0.69-0.30 arasında olması orta, 0.29-0.01 arasında olması zayıf bir ilişki olarak ifade edilmektedir (Büyüköztürk vd., 2017:113). Korelasyon katsayısının pozitif olması, değişkenler arasında doğrusal yönlü bir ilişkinin olduğunu; negatif olması ise ters yönlü bir ilişki olduğunu göstermektedir (Büyüköztürk, 2005:31-32).

Tablo 7. Destinasyon Kişiliği ile Ziyaret Memnuniyeti ve Davranışsal Niyetler Arasındaki İlişkiye Yönelik Korelasyon Analizi Bulguları

\begin{tabular}{|c|c|c|c|c|c|c|c|}
\hline & & 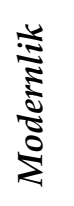 & 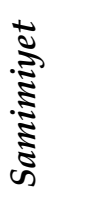 & 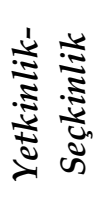 & 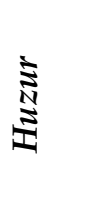 & 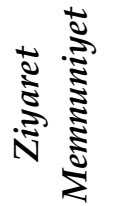 & 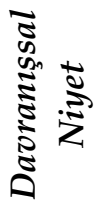 \\
\hline \multirow[t]{2}{*}{ Modernlik } & Spearman & 1 &, $362^{* *}$ & $498^{* *}$ &, $308^{* *}$ &, $266^{* *}$ &, $333^{* *}$ \\
\hline & Anlamlılık & & ,000 & ,000 & ,000 & ,000 & ,000 \\
\hline \multirow[t]{2}{*}{ Samimiyet } & Spearman & & 1 & $400^{* *}$ &, $353^{* *}$ &, $227^{* *}$ &, $258^{* *}$ \\
\hline & Anlamlilık & & & ,000 & ,000 &, 000 &, 000 \\
\hline \multirow{2}{*}{$\begin{array}{l}\text { Yetkinlik- } \\
\text { Seçkinlik }\end{array}$} & Spearman & & & 1 & $262^{* *}$ & $241^{* *}$ & $284^{* *}$ \\
\hline & Anlamlılık & & & & ,000 & ,000 & ,000 \\
\hline \multirow[t]{2}{*}{ Huzur } & Spearman & & & & 1 &, $182^{* *}$ & $223^{* *}$ \\
\hline & Anlamlılık & & & & & ,000 & ,000 \\
\hline \multirow{2}{*}{$\begin{array}{c}\text { Ziyaret } \\
\text { Memnuniyet }\end{array}$} & Spearman & & & & & 1 & $831^{* *}$ \\
\hline & Anlamlılık & & & & & &, 000 \\
\hline \multirow{2}{*}{$\begin{array}{c}\text { Davranışsal } \\
\text { Niyet }\end{array}$} & Spearman & & & & & & 1 \\
\hline & Anlamlılık & & & & & & \\
\hline
\end{tabular}

** Korelasyon p<0,01; p:0,000 düzeyinde anlamlıdır $(\mathrm{N}=411)$

Tablo 7'de destinasyon kişiliğini oluşturan boyutlar ile ziyaretçilerin memnuniyetleri ve davranışsal niyetleri algılamaları arasındaki korelasyon katsayıları sunulmuştur. Genel olarak destinasyon kişiliğinin tüm boyutları ile turistlerin memnuniyet ve davranışsal niyetleri arasındaki korelasyon katsayıları p<0,05; p:0,000 düzeyinde pozitif yönlü ve anlamlı olduğu görülmektedir. Analiz sonuçlarına göre "modernlik" boyutu (r: 266), "yetkinlik-seçkinlik" boyutu (r: 241), "samimiyet" boyutu (r: 227) ve "huzur" boyutu (r: 182) ile memnuniyet arasinda pozitif bir ilişki vardır. Ancak güçlü olmayan ilişkilerdir.

Genel olarak davranışsal niyetler ile en yüksek ve anlamlı korelasyon sergileyen boyut "modernlik" boyutudur (r: 333). Analiz sonuçlarına göre "modernlik" boyutu ve "davranışsal niyetler" ölçeği arasında pozitif ve orta düzeyde bir ilişki vardır. "Yetkinlik-seçkinlik" boyutu (r: 284), "samimiyet" boyutu (r: 258) ve "huzur" boyutu (r: 223) ile "davranışsal niyetler" ölçeği arasında pozitif ve zayıf düzeyde bir ilişki vardır. Söz konusu ilişkilerin hepsinin pozitif yönlü, fakat güçlü olmadığı sonucuna ulaşılmıştır. Analiz edilen değişkenlerden destinasyon kişiliğinin "modernlik" boyutunun "davranışsal niyetler" ölçeği ile ilişkisinin diğer değişkenlerin ilişkilerinden daha güçlü olduğu görülmektedir. Diğer bir ifade ile "modernlik" boyutu kuvvetlendikçe turistlerin "davranışsal niyetleri" nin de daha olumlu olabileceği söylenebilir. 
Son olarak "ziyaret memnuniyeti" ölçeği ile "davranışsal niyetler" ölçeği arasındaki ilişki incelenmiştir. Bu iki ölçek arasında anlamlı ve pozitif yönlü güçlü bir ilişki (r: 831) olduğu tespit edilmiştir.

\section{SONUÇ VE TARTIŞMA}

Turizm sektörünün sosyo-ekonomik kalkınmadaki yeri azımsanmayacak düzeydedir. Bu yüzden turizmden pay almak isteyen ülkelerin sahip oldukları destinasyonları en iyi ve etkili şekilde pazarlamaları önemlidir. Olumlu bir destinasyon imajı geliştirmek ve belirlenen hedef turist özellikleri doğrultusunda destinasyon kişiliği oluşturmak, destinasyonu pazarlamada ciddi katkılar sağlamaktadır (Sağlık ve Türkeri, 2015:37). Turistler tarafından algılanan destinasyon kişiliği destinasyon imajı üzerinde doğrudan bir belirleyicidir (Kanıbir vd., 2010:79).

İlgili araştırmalar incelendiğinde destinasyon kişiliğinin sadakat, imaj, memnuniyet, tavsiye etme ve satın alma niyeti üzerinde etkili bir destinasyon pazarlama aracı olduğu anlaşılmaktadır (Türkmen ve Köroğlu, 2017: 423). Bu nedenle destinasyon kişiliği, bir destinasyonun marka haline getirilmesini sağlayan en önemli yardımcı unsurlardan biridir (Murphy vd., 2007; Kanıbir vd., 2010; Usakli ve Baloglu, 2011; Kılıç ve Sop, 2012; Chen ve Phou, 2013; Xie ve Lee, 2013; Artuğer ve Çetinsöz, 2014; Uca Özer, 2015; Umur ve Eren, 2015; Sağlık ve Türkeri, 2015; Ural vd. 2016; Ülkü vd. 2017; Türkmen vd. 2018). Oluşturulacak destinasyon kişilikleri turistlerin duygularına hitap ederek kendi kişilik özelliklerini destinasyon ile bütünleştirmesine yardımcı olur ve destinasyona yönelik duygusal bir bağlılık meydana getirebilir. Bu bağlılık da sadakatle sonuçlanabilir (Uca Özer, 2015:133).

Gastronomi turizmi bağlamında "marka kent" kabul edilen Gaziantep, sahip olduğu yöresel yemekleri, el sanatları, çarşıları, camileri, tarihi evleri, kaleleri, hanları, hamamları, müzeleri ile kültürel mirasımıza ait birçok unsuru bir arada bulundurmaktadır (https://gaziantep.ktb.gov.tr). $\mathrm{Bu}$ araştırmada, yerli turistler tarafından Gaziantep ilinin hangi destinasyon kişiliği unsurları ile algılandığı ve bu unsurların memnuniyet ve davranışsal niyetler ile ilişkisi ortaya konulmaya çalışılmıştır. Bunun için Gaziantep'i ziyaret eden 411 yerli turistten anket yöntemi ile veri toplanmıştır. Gaziantep'in destinasyon kişiliğini ortaya koymak için Aaker'ın (1997) Marka Kişiliğgi Ölçeğii'nden yararlanılmışır. 411 turiste uygulanan anketlerden elde edilen verilere analizler uygulanmış ve elde edilen bulgular yorumlanmıştır.

Yapılan faktör analizi sonucunda 17 ifade ve dört boyuttan oluşan bir faktör yapısı elde edilmiştir. Gaziantep'in kişilik yapısı "modernlik", "samimiyet", "yetkinlik-seçkinlik" ve "huzur" boyutlarıyla açılanmıştır. Bu kişilik boyutları, orijinal ölçekle büyük ölçüde uyum sağlamıştır. Ancak bazı ifadeler orijinal ölçeğe göre farklı boyutlar altında yer almıştır. Bu durum daha önce yapılan çalışmalarda da görülmektedir (Sahin ve Baloglu, 2011; Usakli ve Baloglu, 2011; Kılıç ve Sop, 2012; Chen ve Phou, 2013; Sağlık ve Türkeri, 2015; Umur ve Eren, 2015).

Literatürde yer alan destinasyon kişiliği çalışmalarının birçoğunda farklı boyutlar ortaya çıkmıştır. Destinasyon kişiliğinin farklı boyutlarda ortaya çıkması, araştırma yapılan destinasyonun kültürel yapısı ile farklı turistik özellikler taşımasından kaynaklanmaktadır. Destinasyon kişiliğinin üç boyutta (Ekinci ve Hosany, 2006; Türkmen ve Köroğlu, 2017; Ülkü vd., 2017), dört boyutta (Kılıç ve Sop, 2012; Ye, 2012; Xie ve Lee, 2013; Artuğer ve Ercan, 2015; Sağlık ve Türkeri, 2015), ve beş boyutta (Sahin ve Baloglu, 2011; Usakli ve Baloglu, 2011; Chen ve Phou, 2013; Kim ve Lehto, 2013; Umur ve Eren, 2016; Atay ve Dülgaroğlu, 2017) ortaya çıktığı çalışmalar mevcuttur. Bu çalışmada da Gaziantep'in destinasyon kişiliği dört boyutta ortaya çımıştır.

Modernlik olarak adlandırılan destinasyon kişiliği boyutu "çağdaş, güvenilir, bağımsız, batılı" kişilik özelliklerinden oluşmaktadır. Atay ve Dülgaroğlu'nun (2017) yaptıkları çalışmada "batılı 
ve çağdaş" ifadeleri tek bir boyut altında çıkmıştır ve onlar da bu boyutu modernlik olarak isimlendirmiştir. Türk toplumunda batılılık, çağdaşlık ve bağımsızlık modernlik olarak algılandığından ilgili ifadelerin ayrı bir boyut altında toplandığı düşünülmektedir (Atay ve Dülgaroğlu, 2017:392-393; Türkmen ve Köroğlu, 2017:416; Ülkü vd., 2017:993). Bu yüzden bu boyut" modernlik" olarak adlandırılmıştır.

"Samimiyet" olarak adlandırılan boyut "neşeli, cana yakın, yaşam dolu, özgün" kişilik özelliklerinden oluşmaktadır. Aaker'ın (1997) "marka kişiliği" ölçeğinde samimiyet ve heyecan boyutunda bulunan bu ifadeler Artuğer ve Çetinsöz (2014) ile Türkmen ve Köroğlu'nun (2017) çalışmasında "samimiyet" boyutunda, Türkmen vd.'nin (2018) çalışmasında "heyecan" boyutunda, Kılıç ve Sop'un (2012) çalışmasında ise "dinamizm" boyutunda ortaya çıkmıştır. Bu çalışmada ise "samimiyet" olarak isimlendirilmiştir.

"Yetkinlik-seçkinlik" olarak adlandırılan boyut "zengin sınıflı, özgüvenli, zeki, başarılı, güçlü, çekici, iyi görünümlü" kişilik özelliklerinden oluşmaktadır. Aaker'ın (1997) "marka kişiliği" ölçeğinde "yetkinlik ve seçkinlik" boyutlarında bulunan ifadeler destinasyon kişiliğini ölçen bazı çalışmalarda tek bir boyut altında ortaya çıkmıştır. Türkmen ve Köroğlu (2017) ile Türkmen vd., (2018) de bu boyutu "yetkinlik-seçkinlik" olarak isimlendirmiştir. Bu çalışmada da benzer bir sonuç çıktığı için "yetkinlik-seçkinlik" olarak adlandırılmıştır.

"Huzur" olarak adlandırılan boyut "aile odaklı ve aklı başında" kişilik özelliklerinden oluşmaktadır. Aaker'in (1997) ölçeğinde "samimiyet" boyutunda bulunan bu ifadeler, benzer çalışmaların birçoğunda da "samimiyet" boyutunda yer almıştır (Kanıbir vd., 2010; Türkmen ve Köroğlu, 2017; Türkmen vd., 2018). Fakat bu çalışmada ayrı bir boyut halinde ortaya çıkmıştır. Aile odaklı yerler Türk toplumunda huzuru çağrıştırdığı için bu boyut "huzur" olarak isimlendirilmiştir.

Araştırmada, Gaziantep'i ziyaret eden yerli turistlerin destinasyon kişiliği algılamaları ile memnuniyetleri ve davranışsal niyetleri arasında pozitif ve istatistiksel açıdan anlamlı bir korelasyon bulunmuştur. Bu sonuç, konu ile ilgili daha önce yapılmış çalışmaların sonuçları ile benzerlik göstermektedir. Önceki çalışmalar destinasyon kişiliğinin turistlerin memnuniyetleri ve davranışsal niyetleri üzerinde olumlu bir etkiye sahip olduğunu göstermektedir (Murphy vd., 2007; Usakli ve Baloglu, 2011; Kılıç ve Sop, 2012; Umur ve Eren, 2015; Ural vd., 2016; Ülkü vd. 2017; Türkmen vd., 2018). Fakat araştırmada söz konusu ilişkilerin genel olarak zayıf olduğu sonucuna ulaşılmıştır. Bu sonuca göre destinasyon kişiliğinin memnuniyet açısından tek başına yeterli olmadığı söylenebilir.

Destinasyon kişiliği ile birlikte destinasyon imajı, destinasyon sadakati ve destinasyon aidiyeti gibi faktörlerin de memnuniyeti ve davranışsal niyetleri artırabileceği düşünülmektedir. Literatürde yer alan çalışmalar, imaj, aidiyetlik vb. marka unsurlarının destinasyon memnuniyeti ve davranışsal niyetler ile olumlu yönde ilişkisi olduğunu göstermektedir (Sevim vd., 2013; Bezirgan, 2014; Umur ve Eren, 2015; Ural vd., 2016; Uğur vd., 2018). Analiz sonucunda sadece "modernlik" boyutu davranışsal niyetler ile biraz daha yüksek korelasyon sergilemiştir. Bu sonuç, katılımcıların genellikle eğitim ve gelir düzeyi yüksek gruplardan oluşması ile açılanabilir. Buradan hareketle Gaziantep'in "çağdaş, güvenilir, bağımsız, batılı" olmasının destinasyona gelen yerli turistlerin, gelecekte tekrar Gaziantep'i ziyaret etmelerini ve tanıdıklarına Gaziantep'i turistik bir destinasyon olarak tavsiye etmelerini etkilediği söylenebilir.

\section{ÖNERİLER}

Sosyal bilimlerde yapılan birçok araştırma gibi bu araştırmanın da sınırlılıkları vardır. Zaman ve maliyet konusundaki kısıtlar nedeniyle çalışma Gaziantep'te gerçekleştirilmiştir. Bu çalışma, 
katılımcıların görüşleri ile sınırlıdır. Araştırmanın diğer bir sınırlılı̆̆ı ise araştırma verilerinin yalnızca yerli turistlerden toplanması, Gaziantep'i ziyaret eden yabancı turistlerin bu araştırma kapsamına dâhil edilmemesidir. Farklı destinasyonlarda yapılacak ölçümler ile karşılaştırmalar yapilabilir.

Konuyla ilgilenen araştırmacılar, Türkiye'nin farklı destinasyonlarında destinasyon kişiliğini analiz eden çalışmalar yapabilirler. Bu sayede birçok önemli destinasyonun kişilik yapısı ortaya konulabilir. Destinasyon çekiciliği bakımından birbirine benzeyen destinasyonların kişilik yapılarının incelenmesiyle benzer destinasyonlar arasındaki farklılıklar belirlenebilir (Sop vd., 2012:1135). Bu sayede merkezi ve yerel yönetimlerin destinasyonlara ilişkin tanıtım planlamasına katkı sunulabilir. Bununla birlikte, destinasyon kişiliği ve destinasyon imajı, destinasyon sadakati, destinasyon aidiyetliği vb. farklı marka unsurlarını bir arada barındıran çalışmaların yapılması da önerilmektedir.

Gaziantep'in destinasyon kişiliğinin sadece yerli turistler için değil, yabancı turistler için de incelenmesi ve destinasyon kişiliğinin yabancı ziyaretçilerin gözünden de değerlendirilmesi araştırmacılara önerilmektedir. Destinasyon kişiliğinin turistlerin memnuniyet düzeyleri ve davranışsal niyetleri üzerindeki pozitif etkisi incelendiğinde, turizm işletmeleri ve yerel yönetimler tarafından Gaziantep'in sahip olduğu kişilik yapısı dikkate alınarak pazarlama stratejilerinin belirlenmesi Gaziantep'e yönelik turist hareketliliğini arttırabilir.

Yoğun bir şekilde iç ve dış göç alan Gaziantep'in "huzur" boyutu kullanılarak faaliyetlerinin yapılması olumlu algının yaygınlaştırılmasına katkı sunabilir. Göç almasına rağmen huzurlu bir şehir olarak algılanan Gaziantep'in tanıtımı ve reklam çalışmalarında bu unsur ön plana çlkarılabilir. Gaziantep'in "huzur" imajının pazarlama stratejileri (reklamlar, tanıtımlar, sosyal sorumluluk projeleri) kapsamında değerlendirilmesi tarafımızca tavsiye edilmektedir. Bu sayede şehri kısa süreliğine ziyaret eden turistlerin konaklama sürelerinin artırılmasının yanında turizmden elde edilecek ekonomik faydayı da yükselteceği düşünülmektedir.

Gaziantep'te aile odaklı huzuru çağrıştıran birçok tabiat parkı ve mesire alanı bulunmaktadır. Örneğin; Gaziantep şehir merkezinde bulunan Burç tabiat parkı (ve içerisinde hayvanat bahçesi), Dülükbaba tabiat parkı, Botanik bahçesi, Erikçe kent ormanı, Alleben tabiat parkı; İslahiye ilçesinde bulunan Yesemek Açık Hava Müzesi ve Huzurlu tabiat parkı (Hınzırlı yaylası) ile Yavuzeli ilçesinde bulunan Rumkale bunlardan en çok öne çıkanlarıdır. Bu mekânlar Gaziantep'in huzur imajı için değerlendirilebilir. Doğayla iç içe olan bu mekânların reklam ve tanıtımlarının yapılmasıyla huzur imajı pekiştirilebilir.

\section{KAYNAKÇA}

Aaker, J. L. (1997). Dimensions of Brand Personality, Journal of Marketing Research, 34(3): 347-356.

Altunışık, R., Coşkun, R., Bayraktaroğlu, S. ve Yıldırım, E. (2007). Sosyal Bilimlerde Araştırma Yöntemleri: Spss Uygulamalı. (5. Basım), Sakarya: Sakarya Yayıncılık.

Altunışık, R. (2008). Anketlerde Veri Kalitesinin İyileştirilmesi İçin Öntest (Pilot Test) Yöntemleri, Pazarlama ve Pazarlama Araştırmaları Dergisi, 2: 1-17.

Artuğer, S. ve Çetinsöz, B.C. (2014). Destinasyon İmajı ile Destinasyon Kişiliği Arasındaki İlişkiyi Belirlemeye Yönelik Bir Araştırma, İşletme Araştırmaları Dergisi, 6(1): 366-384.

Artuğer, S. ve Ercan, F. (2015). Marmaris'in Destinasyon Kişiliğini Belirlemeye Yönelik Bir Araştırma, Uluslararası Sosyal Araştırmalar Dergisi, 8(36): 787-793. 
Atay, L. ve Dülgaroğlu, O. (2017). Markalaşma Açısından Cunda Adası'nın Destinasyon Kişiliğinin Tespitine Yönelik Bir Çalışma, Balıkesir Üniversitesi Sosyal Bilimler Enstitüsü Dergisi, 20(38): 383-396.

Bezirgan, M. (2014). Turistik Destinasyonda Fiyat Değeri, Aidiyet ve Davranışsal Niyetler Arasındaki İlişkilerin Belirlenmesi: Kemer Örneği, Akademik Sosyal Araştırmalar Dergisi, 2(5): 524539.

Büyüköztürk, Ş. (2005). Sosyal Bilimler İçin Veri Analizi El Kitabı. (5. Basım), Ankara: Pegem A Yayıncilik.

Büyüköztürk, Ş., Çakmak, E. K., Akgün, Ö. E., Karadeniz, Ş. ve Demirel, F. (2017). Bilimsel Araştırma Yöntemleri. (23. Basım), Ankara: Pegem Akademi Yayıncılık.

Chen, C. F. and Phou, S. (2013). A Closer Look at Destination: Image, Personality, Relationship and Loyalty. Tourism Management, (36): 269-278.

Çetinsöz, B.C. ve Atsan, M. (2018). Anamur İlçesinin Marka Kimliği ve Kişiliği Üzerine Bir Araştırma, II. Uluslararası Turizmin Geleceği Kongresi, $27-29$ Eylül 2018. Mersin. ss: 630-639.

Çiğdem, H. ve Kurt, A. A. (2012). Yansıtıcı Düşünme Ölçeğinin Türkçeye Uyarlanması, Uludă̆ Üniversitesi Ĕ̆itim Fakültesi Dergisi, 25(2): 475-493.

Ekinci, Y. and Hosany, S. (2006). Destination Personality: An Application of Brand Personality to Tourism Destinations, Journal of Travel Research, 45: 127-39.

Hankinson, G. (2004). Relational Network Brands: Towards A Conceptual Model of Place Brands, Journal of Vacation Marketing, 10(2): 109-121.

Hosany, S., Ekinci, Y. and Uysal, M. (2006). Destination Image And Destination Personality: An Application of Branding Theories to Tourism Places, Journal of Business Research, 59(5): 638-642.

https://gaziantep.ktb.gov.tr/TR-127980/sinir-kapilarindan-giris-yapan-yerli-yabanci-turist-sayhtml [Erişim Tarihi: 23.08.2019]

İlban, M. O., Bezirgan, M. ve Çolakoğlu, F. (2016). Termal Otellerde Algılanan Hizmet Kalitesi, Memnuniyet ve Davranışsal Niyetler Arasındaki İlişkilerin İncelenmesi: Edremit Örneği, Anatolia: Turizm Araştırmaları Dergisi, 27(2): 181-194.

Kanıbir, H., Nart, S. ve Saydan, R. (2010). Şehir Pazarlamasında Marka Kişiliğinin Etkisi: Algılanan Marka Kişiliği - Turistlerin Tavsiye Etme Davranışı İlişkisi, Pazarlama ve Pazarlama Araştırmaları Dergisi, (6): 53-84.

Karasar, N. (2014). Bilimsel Araştırma Yöntemleri. (27. Basım), Ankara: Nobel Akademik Yayıncılık.

Kılıç, B. and Sop, S. A. (2012). Destination Personality, Self-Congruity and Loyalty, Journal of Hospitality Management and Tourism, 3(5): 95-105.

Kim, S. and Lehto, X. Y. (2013). Projected and Perceived Destination Brand Personalities: The Case of South Korea, Journal of Travel Research, (52): 117-130.

Murphy, L., Benckendorff, P. and Moscardo, G. (2007). Linking Travel Motivation, Tourist Selfİmage and Destination Personality, Journal of Travel and Tourism Marketing, 22(2): 45-61.

Olcay, A. ve Düzgün, M. (2016). Turizm Eğitimi Gören Öğrencilerin Meslek Seçimlerinin Kariyer Çapaları ile Uygunluğunun Değerlendirilmesi, Kastamonu Ĕ̆itim Dergisi, 24(3): 1127-1148.

Özdamar, K. (1999a). Paket Programlar ile İstatistiksel Veri Analizi 1. (2.Basım), Eskişehir: Kaan Kitabevi. 
Özdamar, K. (1999b). Paket Programlar ile İstatistiksel Veri Analizi 2 (Çok Değişkenli Analizler). (2.Basım), Eskişehir: Kaan Kitabevi.

Pereira, R. L. G., Correia, A. D. J. H., and Schutz, R. L. A. (2014). Destination Brand Personality: Searching for Personality Traits on Golf-Related Websites, Anatolia: An International Journal of Tourism and Hospitality Research, 25(3): 387-402.

Sağlık, E. ve Türkeri, İ. (2015). Destinasyon İmajının ve Kişiliğinin Destinasyon Aidiyeti Üzerine Etkisi: Palandöken Kayak Merkezi Örneği, Seyahat ve Otel İşletmeciliği Dergisi, 12(1): 25-42.

Sahin, S. and Baloglu, S. (2011). Brand Personality and Destination Image of İstanbul, AnatoliaAn International Journal of Tourism and Hospitality Research, 22(1): 69-88.

Sevim, B., Seçilmiş, C. ve Görkem, O. (2013). Algılanan Destinasyon İmajının Tavsiye Davranışı Üzerine Etkisi: Safranbolu'da Bir Araştırma, Uluslararası Yönetim İktisat ve İşletme Dergisi, 9(20): 112- 126.

Sipahi, B., Yurtkoru, E.S. ve Çinko, M. (2010). Sosyal Bilimlerde Spss'le Veri Analizi. (3. Basım), İstanbul: Beta Yayıncilik.

Sop, S.A., Kılıç, B. ve Kurnaz, A. H. (2012). Destinasyon Kişiliği ve Memnuniyet İlişkisi: Yerli Turistler Üzerine Bir Araştırma, 13. Ulusal Turizm Kongresi, 6-9 Aralık 2012. Antalya. ss: 1123-1138.

Türkmen, S. ve Köroğlu, A. (2017). Destinasyon Kişiliği Araştırması: Türkiye - Yunanistan Örneği, Balıkesir Üniversitesi Sosyal Bilimler Enstitüsü Dergisi, 20(37): 397-429.

Türkmen, S., Atay, L. ve Türkmen, E. (2018). Destinasyon Kişiliği, Memnuniyet ve Davranışsal Niyetler Arasındaki İlişkinin İncelenmesi: Çanakkale Örneği, Journal of Yasar University, 13(49): 22-32.

Uca Özer, S. (2015). Şehir Pazarlaması Kapsamında Marka Kişiliği ve Marka Sadakati İlişkisi, Beykent Üniversitesi Sosyal Bilimler Dergisi, 8: 118-136.

Uğur, İ., Gökkaya, S. ve Acar, A. (2018). Yerli Turistlerin Destinasyon İmajına İlişkin Tekrar Ziyaret Etme Niyetleri: Safranbolu Üzerine Bir Çalışma, Safran Kültür ve Turizm Araştırmaları Dergisi, 1(1): 29-40.

Umur, M. ve Eren, D. (2016). Destinasyon İmajı ve Destinasyon Kişiliğinin, Ziyaretçi Memnuniyeti ve Geleceğe Yönelik Ziyaretçi Davranışı Üzerine Etkisi: Kapadokya Örneği, Kırıkkale Üniversitesi Sosyal Bilimler Dergisi, 6(1): 271-294.

Ural, A. ve Kılıç, İ. (2013). Bilimsel Araştırma Süreci ve Spss İle Veri Analizi. (4. Basım), Ankara: Detay Yayıncilı.

Ural, T., Tercan, E. ve Arslan, M. (2016). Güçlü Kent Markası Oluşturmada Destinasyon Kişiliğ̈i, Bilişsel ve Duygusal İmajın Rolü: Hatay Örneği, Anadolu Üniversitesi Sosyal Bilimler Dergisi, 16(4): 145-160.

Usakli, A. (2009). The Relationship Between Destination Personality, Self-Congruity A Behavioral Intentions, Thesis University Libraries, University of Nevada, Las Vegas.

Usakli, A. and Baloglu, S. (2011). Brand Personality of Tourist Destinations: An Application of Self-Congruity, Theory. Tourism Management, 32(1): 114-127.

Ülkü, A., Solmaz, S. A. ve Barakazi, M. (2017). Destinasyon Kişiliğinin Turistlerin Davranışsal Niyetleri Üzerindeki Etkisi: Şanlıurfa Örneği, Uluslararası Sosyal Araştırmalar Dergisi, 10(53): 986994. 
Xie, K. L. and Lee, J. (2013). Toward the Perspective of Cognitive Destination Image and Destination Personality: The Case of Beijing, Journal of Travel \& Tourism Marketing, (30): 538-556.

Valette Florence, P., Guizani, H. and Merunka, D. (2011). The Impact of Brand Personality and Sales Promotions on Brand Equity, Journal of Business Research, 64: 24-28.

Yazıcıoğlu, Y. ve Erdoğan, S. (2004). SPSS Uygulamalı Bilimsel Araştırma Yöntemleri. (1. Basım), Ankara: Detay Yayıncilık.

Ye, S. (2012). The Impact of Destination Personality Dimensions on Destination Brand Awareness and Attractiveness: Australia As A Case Study, Turizam: Znanstveno-Stručni Časopis, 60(4): 397409.

Yaşlığlu, M. M. (2017). Sosyal Bilimlerde Faktör Analizi ve Geçerlilik: Keşfedici ve Doğrulayıcı Faktör Analizlerinin Kullanılması, İstanbul Üniversitesi İşletme Fakültesi Dergisi, 46(Özel Sayı): 7485. 